\title{
The effect of e-wom and brand image towards Sushi Masa consumer purchasing decision
}

\author{
Nur Aiman Ikhwan Kamil \\ Corporate Communication Student, Faculty of Communication Science, LSPR \\ Communication and Business Institute Jakarta, Indonesia \\ Email: Ikhwankamil44@gmail.com
}

\section{Albert Albert}

Thesis Department, LSPR Communication and Business Institute Jakarta, Indonesia Email: albert@1spr.edu

\begin{abstract}
This digital age, people are using digital technology to facilitate all kinds of activities. Sushi Masa Jakarta, uses Zomato as one of their media as an E-WOM facility for consumers to express their feelings. In addition, the Authentic Sushi Image cannot be separated from Sushi Masa. The purpose of this study is to find out whether there is effects of E-WOM and Authentic Brand Image towards consumer purchasing decisions, partially and simultaneously. The theory used is Stimulus Response, supported by other marketing communication concepts. The method used is quantitative based on positive paradigm, considers the social reality can be proven scientifically. Data collection used were questionnaires with Likert scale. The results found the effect of E-WOM and Brand Image together towards consumer purchasing decisions by $62.9 \%$. The author suggest that Sushi Masa can maintain E-WOM and Brand Image that has been built so that consumers continue to making purchasing decisions
\end{abstract}

Keywords: E-WOM, Brand Image, Purchase Decisions, Consumer, Sushi. 


\section{Introduction}

In this digital age anything can be done easily, more and more people are using digital technology to facilitate all kinds of their activities. The increasing population in the world is 7.5 billion people, $53 \%$ of which is 4.21 billion are active users of internet media (We Are Social, 2018). In Indonesia, out of a total population of 262 million people, $54.68 \%$ of which 143.26 million are internet users (Kominfo, 2018). Open access is very wide, including to express opinions about a product or service that we use is no longer confusing, because many review applications such as Zomato have facilitated every customer in each restaurant to be able to express what they felt when before buying, when buy, and after buying. After buying is where we give an assessment of the products or services that we have used, whether good or bad, depending on the impression we get, if good, of course we will recommend it to the people closest to us or publish it to the public without any objections, in the science of marketing communication we know it with Word of Mouth.

Word of mouth has a huge influence on people who listen to it or from the company affected by Word of Mouth, because of this Word of Mouth the information obtained is considered more trusted and more independent. In the current digital era Word of Mouth has changed its name to Electronic Word of Mouth. According to Hennig-Thurau et al. (In Cheung \& Thadani, 2010) says "Electronic Word of Mouth communication refers to any positive or negative statement made by potential, actual or former customers about a product or company, which is made available to a multitude of people and institution via the internet "which means that the Electronic Word of Mouth Communication is referring to positive statements from potential customers, current consumers and regular consumers about a product of a company that is made free for many people and institutions through the internet.

Electronic Word of Mouth can be anything, one example is like a review site. According to Goldsmith (in Cheung \& Lee, 2008) said, "it can be exchanged via the internet through a variety of means such as email, instant messaging, homepages, blogs, listservs, forus, online communities, newsgroups, chat rooms, hate sites, review sites and social networking sites. "The occurrence of Electronic Word of Mouth makes new consumers who want to make a purchase pay more attention to reviews in advance on the internet from others who have used the product or service first. When consumers already use existing products or services, if the products are used according to their expectations, they will be satisfied and generally they will recommend it to relatives and family about the 
products that have been used through information delivered via digital.

Likewise with Brand Image, it is very important for companies engaged in the product or service sector to create a brand image of their company. Because brand image is one of the supporting factors so that the company can always be remembered and continuously visited by its consumers. If we want to try a new restaurant, of course we will ask, ask whether the restaurant is good or not, good or bad food will get an impression after eating at the restaurant so that we are completely satisfied with the restaurant we visited to eat. From the PreResearch, 30 people chosen randomly, they tend to find out in advance about the restaurant he wants to eat in, only 4 people who did not choose to find out in advance (Research Processed Data, Pre-Research Survey, October 2018). This data slightly confirms that E-Wom and Brand Image are very important for the sustainability of a company, especially those engaged in food, in this case restaurants.

Zomato is one of the review sites in Indonesia, "Zomato is an online and mobile restaurant search guide that provides in-depth information for more than 250,000 restaurants in 15 countries. The main features of Zomato content include menus, photos, coordinates of each restaurant making it easier for users to find and review restaurants and interact with other foodies. Currently, the site and mobile platform Zomato are accessed by more than 23 million users every month to find places to eat out, find a delivery service, gather in a cafe, or enjoy the nightlife. A user-focused platform makes it easy for restaurant owners to interact directly with their customers. (Destriyana, 2014).

As the times grew, many Indonesian people from all walks of life both young and old liked food from outside Indonesia. One of them is Japanese food, Sushi. Besides being delicious, sushi is also believed to be able to nourish the body and maintain stamina and endurance for its connoisseurs (CNN Indonesia, 2018). With a high content of omega 3 and calcium, and vitamins, can make our body healthy, fit, and protected from various diseases (Maharani, 2019). Therefore, in Jakarta itself there are many sushi restaurants that are still operating and are never empty of visitors. One example is Sushi Masa Jakarta.

Based on the results of the analysis of the authors in the application Zomato \& Safira (2016) Sushi Masa is located in a port at the end of the capital city of Jakarta, precisely located in Pluit, North Jakarta. Its position is very far from the city center. When we want to go there at first we will feel unsure of the existing access, generally when we want to visit the harbor we will be faced with a road that is not good, a dirty atmosphere, and many large-loaded cars. One of the 
things that is unique from Sushi Masa is that it is located right near the harbor but does not make this restaurant empty of visitors. If we want to eat there, we have to be willing to wait in line for a few minutes because the crowd of Sushi Masa restaurants requires employees to use the waiting list system. In addition, the prices offered by Sushi Masa itself tend to be higher than the average price of Sushi in general. One portion of Sushi Maki for example is pegged at a price range of 35 thousand rupiah to 110 thousand rupiah. For the price of the Fresh Hokkaido Bluefin Tuna menu itself is pegged at a price of 75 thousand rupiah to 650 thousand rupiah. (Zomato Apps, 2018). However, difficult access and high prices do not dampen the desire of every Sushi Masa Jakarta consumer to come to the place to enjoy every product in Sushi Masa Jakarta.

In the Zomato app, the rating obtained by Sushi Masa is quite perfect, which is getting a rating of 4.9 out of 5.0 and 1145 (Research Processed Data, October 2018). Reviews that provide an excellent rating of between 4 and 5 . The image obtained by Sushi Masa is also good, namely as one of Authentic Sushi in Jakarta, which means that the ingredients used to make sushi are prepared, processed, and made to the original standard Japanese Sushi. For the sake of maintaining the authenticity of the ingredients and freshness of the product. Restaurants similar to Sushi Masa Jakarta that have the same authentic Sushi image are as follows, there are three restaurants namely Daitokyo Sakaba, Kikugawa, and Marufuku. The following comparison table.

Table 1. Comparison of E-wom with competitors

\begin{tabular}{lllll}
\hline Restaurant & Rating & $\begin{array}{l}\text { Number } \\
\text { Reviews }\end{array}$ & of Positive & Negative \\
\hline Sushi Masa & $4.9-5.0$ & 1145 People & 1093 People & 52 People \\
\hline Daitokyo Sakaba & $4.4-5.0$ & 902 People & 848 People & 54 People \\
\hline Kikugawa & $4.4-5.0$ & 285 People & 273 People & 12 People \\
\hline Marufuku & $4.0-5.0$ & 88 People & 80 People & 8 People \\
\hline \multicolumn{5}{c}{ Source: (Zomato, 2018; Processed Researcher Data, 2018). }
\end{tabular}

Table 2. Comparison of Image with competitors

\begin{tabular}{llllll}
\hline Restaurant & Rating & $\begin{array}{l}\text { Number of } \\
\text { Reviews }\end{array}$ & $\begin{array}{l}\text { Authentic } \\
\text { Sushi }\end{array}$ & $\begin{array}{l}\text { Experience } \\
\text { Review }\end{array}$ & $\begin{array}{l}\text { Didnt leave } \\
\text { comments }\end{array}$ \\
\hline Sushi Masa & $4.9-5.0$ & 1158 People & 76 People & 528 People & 554 People \\
\hline $\begin{array}{l}\text { Daitokyo } \\
\text { Sakaba }\end{array}$ & $4.4-5.0$ & 914 People & 41 People & 419 People & 454 People \\
\hline
\end{tabular}


The effect of e-wom and brand image towards Sushi Masa ... (Nur Aiman Ikhwan Kamil, Albert Albert)

\begin{tabular}{lcllll}
\hline Restaurant & Rating & $\begin{array}{l}\text { Number of } \\
\text { Reviews }\end{array}$ & $\begin{array}{l}\text { Authentic } \\
\text { Sushi }\end{array}$ & $\begin{array}{l}\text { Experience } \\
\text { Review }\end{array}$ & $\begin{array}{l}\text { Didnt leave } \\
\text { comments }\end{array}$ \\
\hline Kikugawa & $4.4-5.0$ & 286 People & 22 People & 143 People & 121 People \\
\hline Marufuku & $4.0-5.0$ & 88 People & 18 People & 37 People & 33 People \\
\hline
\end{tabular}

Source: (Zomato, 2018; Processed Researcher Data, 2018).

Based on this thinking, a study was made with the title "The effect of e-wom and brand image towards Sushi Masa consumer purchasing decision" to see whether these variables have a significant influence on each other, and whether the mass of Sushi Masa is influenced by Electronic Word of Mouth in the zomato application and the Brand Image itself.

\section{Literature Review}

This study refers to the five previous studies conducted by Sari et al. (2017), Finanda \& Wiwaha (2017), Ivana et al. (2014), Soim et al. (2016), Mamahit et al. (2015), the five studies obtained positive and significant results. The relationship between the five previous studies with this research is that the previous research shows that there is a significant influence between Electronic Word of Mouth and Brand Image on purchasing decisions. This research is interesting because this research uses a unique research object that is Sushi restaurant which is expensive but always crowded with visitors, and also the location that is difficult to reach but many consumers still come to eat there, besides the theory used compared to the above research is different, and the sampling and test techniques used are different to determine the effect of E-Wom and Brand Image on Purchasing Decisions of Sushi Consumer in Jakarta.

\section{Stimulus Communication Model-Response}

Zacharis \& Bender, (in Mulyana, 2009) stated that the communication model S - R or Stimulus-Response influenced behavioristic flow. The model that shows communication as a process of action - reaction or cause - effect assumes that the presence of words verbally, both oral and written, or even nonverbal cues will stimulate others to respond in certain ways. This process can also be said as the exchange or transfer of information or ideas that are reciprocal. It was also stated that this communication model has many effects and each of these effects can change the next communication action. Stimulus that works as a cause will result in the response that arises thereafter is a result of receiving messages. 


\section{Marketing}

Marketing is the process of managing a profitable customer relationship. (Kotler \& Armstrong, 2008). In a narrower business context, marketing covers creating value-sharing relationships with profitable customers. Therefore we define marketing as the process by which companies create value for customers and build strong relationships with customers, with the aim of capturing the value of customers in return. (Kotler $\&$ Keller, 2008).

According to the American Marketing Association (AMA) (in Kotler \& Keller, 2008). The formal definition of marketing is an organizational function and a series of processes to create, communicate, and provide value to customers and to manage customer relationships in ways that benefit the organization and its stakeholders (Yunita \& Windarani, 2018)

\section{Marketing Communication}

According to the American Marketing Association (In Belch \& Belch, 2015) The concept of marketing communication planning recognizes the added value of existing comprehensive plans to evaluate the strategic role of various communication disciplines. For example, general advertising, direct response, sales promotion, and public relations, this all combines communication disciplines to provide clarity, consistency, and the impact of maximum communication.

\section{E-WOM}

According to Blackwell et al. (2012) Word of Mouth communication is an informal transmission of ideas, comments, opinions and information between two people, neither of whom are marketers.

According to Goldsmith (in Cheung \& Lee, 2008) states that women can exchange via the internet through variations such as e-mails, short messages, home pages, blogs, listservs, various forums, online communities, news groups, chat communication spaces, hatesite, site review and social networking site.

Hennig-thurau et al. (in Cheung $\&$ Lee, 2008) defines ewom as a positive or negative statement made by a former customer, actual customer, or potential customer about a product or company that is made open to many people or institutions via the internet.

Goyette (in Sari et al., 2017) in measuring the effect of electronic word of mouth using the following indicators: First, Intensity. The intensity in electronic word of mouth is the number of opinions or comments written by 
consumers in a social media. According to Goyette (in Sari et al., 2017) divides the indicators of intensity as follows: Frequency of accessing information from social media; b. Frequency of interaction with social media users; The number of reviews written by social media users

Second, content. According to Goyette (in Sari et al., 2017) Content is the information content of social networking sites relating to products and services. Indicators of content include: Product selection information; Product quality information; Information about prices offered

Third, positive opinion. Positive opinions occur when good news on testimonials and support is desired by the company (Goyette in Sari et al., 2017). Indicators of content include: Positive comments from social media users; Recommendations from social media users.

Fourth, negative opinion. According to Goyette (in Sari et al., 2017) negative opinions are negative comments from consumers about products, services and brands. Includes as follows: Negative comments from social media users; Speak negative things to other people from social media users.

\section{Brand Image}

According to Heding, Knudtzen \& Bjerre (2009), strong and consistent brand personalities can entice people to consume the brand because they feel the personality associated with the brand personality. If brand attributes or behavior (marketing activities) are not consistent with the brand personality, consumers tend to leave the brand because the personality loses credibility. Dimensions of brand personality here include excitement, competence and sophistication.

First is Sincerity (Down-to-earth, Honest, Wholesome, Cheerful). This dimension shows sincere human nature. If applied to the brand this dimension of sincerity reflects how the brand really shows its consistency in meeting the needs (needs), want (desire), and expectation (expectations) of consumers.

Second is Excitement (Online, Spirited, Imaginative, Up to date) Excitement means excitement, how a brand is able to give pleasure to the wearer. Third is Competence (Reliable, Intelligent, Successful). This Competence dimension shows that a brand has the ability to show its presence in the market.

Fourth is Sophisticating (Upper Class, Charming) This dimension refers more to how a brand provides value to its consumers. There are two elements, namely Upper Class and Charming. 
The fifth dimension is Ruggedness (Outdoorsy, Tough). This dimension shows how a brand can survive in the midst of brand competition. The Outdoorsy element refers to the sturdy and masculine nature, while the Tough shows strong elements.

\section{Buying Decision}

According to Kotler and Armstrong (2007), the purchase decision is the final stage in the purchase decision process where consumers actually buy. Furthermore according to Kotler \& Keller (2012) explains that consumer buying behavior is influenced by several factors, namely:

First, cultural factors. Is a state of cultural value systems, customs, and ways of life of people that surround a person's life. Indicators of cultural factors, namely: trust in the product, good and bad views of the product and recommendations for choosing products.

Second, social factors. Is the influence of others both formally and informally. Indicators of social factors, namely: the presence of friends or groups to choose products, the existence of relatives to choose products and the presence of parents to choose products.

Third, personal factors. As a factor that comes from yourself. Personality factor indicators seen from: work and income. Fourth, psychological factors. Indicators of psychological factors seen from motivation, experience and attitude.

\section{Methods}

In this study, researchers used a quantitative method based on a positivistic paradigm, considers the social reality that occurs as something that is empirical and can be actually observed and can be proven scientifically. This research is associative, that is the research model that intends to explain the influence between the variables examined.

The population used in the study are male and female residents who know about Sushi Masa Jakarta and provide reviews in the Zomato app about Sushi Masa Jakarta. Whereas the sample used is the male and female residents in Jabodetabek who have consumed Sushi Masa Jakarta products and provided a review in the Zomato app about Sushi Masa Jakarta. The sampling technique used by researchers is a non probability sampling technique by purposive sampling. In determining the number of respondents, the Slovin formula of 
the existing population is used, namely 1158 people, according to the formula above the results are 92 . Then rounded up to 100 people.

\section{Data Analysis Technique}

\section{Simple Regression Analysis}

According to Sugiyono (2017) a simple regression analysis can be used to predict how high the value of the dependent variable is if the value of the independent variable is manipulated.

Multiple Regression Analysis

According to Sugiyono (2017) multiple regression analysis has the intention of predicting how the state of the dependent variable is if the independent variable is manipulated, in other words the value is up and down.

\section{Test Instrument}

\section{Validity Test}

Measurement validity tells us how well the conceptual and operational definitions work together with each other, the better the fit, the higher the measurement validity. (Neuman, 2017). To calculate the questions already valid (Sarwono \& Jonatan, 2012), then the provisions are: The correlation coefficient (r) must be positive. If the result is negative then the item in question is invalid and must be removed; The value of the correlation coefficient ( $r$ ) results of calculations must be greater than the coefficient value of $r$ table.

\section{Reliability Test}

Reliability means the ability to be relied on or consistency. This shows that the same thing is repeated or happened again under identical or very similar conditions. The opposite of reliability is an uncertain, unstable, or inconsistent result that occurs because of the measurement itself. (Neuman, 2017).

To test the reliability of the instruments that will be used in this study used the Alpha coefficient formula (Sugiyono, 2017).

\section{Normality Test}

Normality test aims to determine the distribution of data that will be used in research. Good and decent data in the variables to be used according to Sujarweni \& Wiratna (2015) is normally distributed data. Normality can be seen using the Kolmogorov-Smirnov Normal test. 
If the significance value is greater than $=0.05$ then the data is normally distributed. Conversely, if the significance value is less than $=0.05$ then the data is not normally distributed (Hamdi \& Bahrudin, 2014).

\section{Multicollinearity Test}

According to Ghozali (in Ayuwardani \& Isroah, 2011) multicollinearity test is used to determine whether there is a correlation between independent variables in the regression model. A good regression model is one that does not contain multicollinearity. Detecting Multicollinearity can see the value of tolerance and variant of inflation factor (VIF) as a benchmark. If the tolerance value $\leq 0.10$ and VIF value $\geq 10$, it can be concluded that in the study there was multicollinearity (Ghozali in Ayuwardani \& Isroah, 2011).

\section{Heteroscedasticity Test}

According to Ghozali (in Ayuwardani \& Isroah, 2011) heteroscedasticity test is used to test whether in a regression there is an unequal variance in residuals from one observation to another observation. The prerequisite that must be fulfilled in the regression model is the absence of heteroscedasticity symptoms. In this research, heteroscedasticity test will be conducted using a glacier test that is correlating the absolute value of residuals with each variable. The results of the glacier test showed there was no heteroscedasticity if from the SPSS calculation the significance probability value was above the $5 \%$ confidence level (Ghozali in Ayuwardani \& Isroah, 2011).

\section{Result and Discussion}

From the description of the characteristics of respondents in this study it can be seen that as many as $89 \%$ are aged $18-24$ years. Then, for the work of Sushi Masa consumers themselves more are still students, this proves that many Masa Masa consumers are still young, and many young people are fond of eating Sushi and are aware of maintaining health, as researchers have pointed out in the background that Sushi can be healthy because it contains high omega 3. For the domicile of Sushi Masa consumers in this study as many as 50\% came from East Jakarta, quite surprising because the location of Sushi Masa is very far but does not discourage consumers to keep coming and tasting Sushi Masa. 
The effect of e-wom and brand image towards Sushi Masa ... (Nur Aiman Ikhwan Kamil, Albert Albert)

\section{Determination Coefficient Test}

Table 1. Determination Coefficient Test

Model Summary

\begin{tabular}{lcrrr}
\hline Model & R & R Square & $\begin{array}{c}\text { Adjusted R } \\
\text { Square }\end{array}$ & $\begin{array}{l}\text { Std. Error of } \\
\text { the Estimate }\end{array}$ \\
\hline 1 & $.793^{\mathrm{a}}$ & .629 & .622 & 7.275 \\
\hline
\end{tabular}

a. Predictors: (Constant), Total X2, Total X1

Based on the Summary Model table above, it can be seen that the coefficient of determination or R Square is 0.629 . The magnitude of the coefficient of determination (R Square) is 0.629 or equal to $62.9 \%$, this number implies that the variables $\mathrm{X} 1$ and $\mathrm{X} 2$ variables simultaneously together affect the Y variable by $62.9 \%$. While the rest $(100 \%-62.9 \%=37.1 \%)$ is affected by other variables outside this regression equation.

\section{Simple Regression Test}

\section{Table 2. Simple Regression Test}

Coefficients $^{\mathrm{a}}$

\begin{tabular}{|c|c|c|c|c|c|c|}
\hline & \multirow[b]{2}{*}{ Model } & \multicolumn{2}{|c|}{$\begin{array}{c}\text { Unstandardized } \\
\text { Coefficients }\end{array}$} & \multirow{2}{*}{$\begin{array}{c}\begin{array}{c}\text { Standardized } \\
\text { Coefficients }\end{array} \\
\text { Beta }\end{array}$} & \multirow[b]{2}{*}{$t$} & \multirow[b]{2}{*}{ Sig. } \\
\hline & & B & Std. Error & & & \\
\hline \multirow[t]{2}{*}{1} & (Constant) & 21,462 & 5,955 & & 3,604 & ,000 \\
\hline & TotalX1 & 1,001 & ,097 & ,717 & 10,291 & ,000 \\
\hline
\end{tabular}

a. Dependent Variable: TotalY

From the results of the simple regression test above, testing the $\mathrm{X} 1$ variable against the $\mathrm{Y}$ variable can be seen that the constant value of the unstandardized coefficient is 21.462. This figure shows that if there is no E-WOM (X1), the Purchase Decision (Y) value is 21.462. The regression coefficient value is 1,001 . Then entered into the regression equation becomes $\mathrm{Y}=21,462+1,001 \mathrm{X}$. This figure means that every $1 \%$ addition of E-WOM (X1), the Purchase Decision will increase by 1,001 . So from the test results above it can be said that the variable $(\mathrm{X} 1)$ has a positive effect on the variable $(\mathrm{Y})$. 
Journal of Social Studies (JSS), Volume 16, Number 1, 2020: 19-34

Table 3. Simple Regression Analysis of $\mathrm{X} 2$ with respect to $\mathrm{Y}$

Coefficients $^{\mathrm{a}}$

\begin{tabular}{|c|c|c|c|c|c|c|}
\hline & \multirow[b]{2}{*}{ Model } & \multicolumn{2}{|c|}{$\begin{array}{c}\text { Unstandardized } \\
\text { Coefficients }\end{array}$} & \multirow{2}{*}{$\begin{array}{c}\text { Standardized } \\
\text { Coefficients } \\
\text { Beta } \\
\end{array}$} & \multirow[b]{2}{*}{ 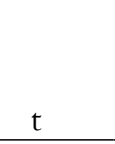 } & \multirow[b]{2}{*}{ Sig. } \\
\hline & & B & Std. Error & & & \\
\hline \multirow[t]{2}{*}{1} & (Constant) & 10,193 & 6,033 & & 1,689 & ,094 \\
\hline & TotalX2 & 609, & ,051 & ,769 & 12,022 & ,000 \\
\hline
\end{tabular}

a. Dependent Variable: TotalY

From the results of the simple regression test above, testing the $\mathrm{X} 2$ variable against the $\mathrm{Y}$ variable can be seen that the constant value of the unstandardized coefficient is 10.193. This figure shows that if there is no Brand Image (X2), the Purchase Decision value $(\mathrm{Y})$ is 10.193 . The regression coefficient value is 0.609 . Then entered into the regression equation becomes $Y=10.193+0.609$ $\mathrm{X}$. This figure implies that each additional 1\% Brand Image (X2), the Purchase Decision will increase by 0.609 . So from the test results above it can be said that the variable $(\mathrm{X} 2)$ has a positive effect on the variable $(\mathrm{Y})$.

\section{Multiple Regression Test}

Table 4. Coefficient Table of Multiple Regression Analysis

Coefficients $^{\mathrm{a}}$

\begin{tabular}{|c|c|c|c|c|c|c|}
\hline & \multirow[b]{2}{*}{ Model } & \multicolumn{2}{|c|}{$\begin{array}{c}\text { Unstandardized } \\
\text { Coefficients }\end{array}$} & \multirow{2}{*}{$\begin{array}{c}\text { Standardized } \\
\text { Coefficients } \\
\text { Beta }\end{array}$} & \multirow[b]{2}{*}{$t$} & \multirow[b]{2}{*}{ Sig. } \\
\hline & & B & Std. Error & & & \\
\hline \multirow[t]{3}{*}{1} & (Constant) & 7.001 & 5.921 & & 1.182 & .240 \\
\hline & TotalX1 & .407 & .137 & .293 & 2.982 & .004 \\
\hline & TotalX2 & .429 & .078 & .544 & 5.528 & .000 \\
\hline
\end{tabular}

a. Dependent Variable: TotalY

Based on the table above it can be said that the Total of Variable X1, namely Electronic Word of Mouth is 0.407 . While the Total of Variable X2, namely Brand Image has a value of 0.429 .

\section{Conclusion}

From the results of existing studies it can be concluded that the results obtained are positive and also significant: There is a significant influence of the 
Electronic Word of Mouth Variable (X1) in the Zomato application towards the Consumer Purchase Decision Variable (Y) of Sushi Masa Jakarta; There is a significant influence of Authentic Sushi Brand Image (X2) Variables towards Consumer Purchase Decision (Y) of Sushi Masa Jakarta; There is a significant effect of the Electronic Word of Mouth Variable (X1) and also the Brand Image (X2) simultaneously towards the Consumer Purchase Decision (Y) of Sushi Masa Jakarta.

\section{REFERENCES}

Ayuwardani, R. P., \& Isroah, I. (2018). Pengaruh informasi keuangan dan non keuangan terhadap underpricing harga saham pada perusahaan yang melakukan initial public offering (Studi empiris perusahaan go public yang terdaftar di Bursa Efek Indonesia tahun 2011-2015). Nominal: Barometer Riset Akuntansi dan Manajemen, 7(1), 143-158.. DOI, :https:// doi.org/10.21831/nominal.v7i1.19781

Belch, G. E., \& Belch, M.A. (2015). Advertising and promotion, An integrated marketing communication perspective. Global Edition. Singapore: Mc Graw Hill Education.

Blackwell, R.D., Miniard, P.W., Engel, J.F., Di-ching, P., Yasin, N.M. \& Hood, W.J. (2012). Consumer behavior. Singapore: Cengage Learning.

Cheung, C.M.K., \& Lee, M.K.O. (2008). Online consumer reviews: Does negative electronic word-of-mouth hurt more?. Proceedings of the Fourteenth Americas Conference on Information Systems (AMCIS). 143. 1-10. DOI:https://doi.org/10.1016/j.dss.2012.01.015

Cheung, C.M.K., \& Thadani, D. R. (2010). The effectiveness of electronic wordof-mouth communication: A literature analysis. 23rd Bled Econference Etrust: Implications for the Individual, Enterprises and Society; Bled, Slovenia. 23, 329-345. DOI:https://doi.org/10.1016/j.dss.2012.06.008

CNN Indonesia. (2018, November, 8). 6 tips enak makan sushi yang paling

Destriyana. (2014). Berjuta alasan Zomato memperluas operasionalnya... https:// www.merdeka.com/teknologi/berjuta-alasan-zomato-memperluasoperasionalnya-di-indonesia.html Accessed 13 October 2018.

Finanda, R. I., \& Wiwaha, A. (2017). Pengaruh word of mouth dan brand image terhadap keputusan penggunaan salon kecantikan pada konsumen 
Miloff Beauty Bar. Jurnal Ilmiah WIDYA Ekonomika 1(2), 134-140.

Hamdi \& Bahruddin. (2014). Metode penelitian kuantitatif aplikasi dalam pendidikan. Yogyakarta: Deepublish.

Heding, T., Knudtzen, C.F., \& Bjerre, M. (2009). Brand management, research, theory, and practice. New York. NY: Routledge.

Ivana, V., Sari, A., \& Thio, S. (2014). Electronic Word-of-mouth (E-wom) Dan Pengaruhnya Terhadap Keputusan Pembelian Di Restoran Dan Kafe Di Surabaya. Jurnal Hospitality dan Manajemen Jasa, 2(2), 218-230.

Kominfo (2018, 02, 19). Jumlah pengguna internet 2017 meningkat, kominfo terus lakukan... https://kominfo.go.id/index.php/content/ detail/12640/siaran-pers-no-53hmkominfo022018-tentang-jumlahpengguna-internet-2017-meningkat-kominfo-terus-lakukan-percepatanpembangunan-broadband/0/siaran_pers Accessed 21 October 2018.

Kotler, P., \& Amstrong, G. (2007). Manajemen pemasaran (Edisi 12, Jilid 1). Jakarta: PT.Index Kelompok Gramedia.

Kotler, P., \& Amstrong, G. (2008). Prinsip-prinsip pemasaran (Edisi 12, Jilid 1). Jakarta: Erlangga.

Kotler, P., \& Amstrong, G. (2011). Principles of marketing 14th edition: New Jersey: Person Education.

Kotler, P., \& Keller, K. L. (2008). Manajemen pemasaran (Edisi 13, Jilid 1). Jakarta: Erlangga

Kotler, P., \& Keller, K. L. (2012). Marketing management. New Jersey: Pearson Prentice Hall, Inc.

Maharani, S. 2019. selain untuk kesehatan jantung, ini 5 manfaat makan sushi. $\quad$ https://kumparan.com/@kumparanfood/selain-untukkesehatan-jantung-ini-5-manfaat-makan-sushi-1rbGyyEOD4r?utm_ source=msnid\&utm_medium=Aggregator Accessed 18 Agust 2019.

Mamahit, P., \& Soegoto, A. S., Tumbuan,.W. A. (2015). Pengaruh brand image, brand trust, dan kualitas produk terhadap keputusan pembelian mobil Toyota All New Yaris pada PT. Hasjrat Abadi Manado. Jurnal Berkala Ilmiah Efisiensi, 15 (5), 777-787.

Mulyana, D. (2009). Ilmu komunikasi. Bandung: PT Remaja Rosdakarya

Neuman, W. L (2017). Metode penelitian sosial: Pendekatan kualitatif dan kuantitatif. Jakarta: Gramedia 
Purnamasari, D. \& Yulianto, E. (2018). Analisis electronic word of mouth terhadap keputusan pembelian produk smartphone oppo dengan brand image dan brand trust sebagai variabel moderator. Jurnal Administrasi Bisnis (JAB) 54 (1). 92-100.

Safira, M. (2016). Sushi Masa: Sushi dan Sashimi tersegar di dekat pelabuhan ikan. https://food.detik.com/resto-dan-kafe/d-3225184/sushi-masasushi-dan-sashimi-tersegar-di-dekat-pelabuhan-ikan Accessed 19 June 2019.

Sari, N., (2017). Pengaruh electronic word of mouth terhadap keputusan pembelian pada Bukalapak.com. Jurnal Manajemen Magister, 3(1), 96-105.

Sarwono \&Jonathan. 2012. Metode riset skripsi pendekatan kuantitatif(Menggunakan prosedur SPSS): Tuntunan praktis dalam menyusun skripsi. Jakarta: PT. Elex Media Computindo.

sehat. https://www.cnnindonesia.com/gaya-hidup/20181108112055-262344915/6-tips-enak-makan-sushi-yang-paling-sehat Accessed 19 Agust 2019.

Silverman, G. (2011). The secret of WOM marketing. Second Edition. New York: Amacom.

Soim, F.M., Suharyono, \& Abdillah, Y. (2016). Pengaruh Brand Image Terhadap Keputusan Pembelian (Studi Pada Pembeli Kartu Perdana Simpati di Booth Telkomsel Matos). Jurnal Administrasi Bisnis (JAB) 35 (1). 146-153.

Sugiyono. (2017). Metode penelitian: Kuantitatif, kualitatif dan REDD. Bandung: Penerbit Alfabeta.

Sujarweni, V., \& Wiratna. 2015. Metodologi penelitian bisnis $\mathcal{E}$ ekonomi. Yogyakarta: Pustaka Baru Press.

We Are Social. (2018). Digital around the world. https://wearesocial-net. s3.amazonaws.com/wp-content/uploads/2018/01/DIGITAL-IN-2018001-GLOBAL-OVERVIEW-V1.00.png Accessed 13 October 2018.

Yunita, R. D., \& Windarani, N. A. (2018). Influence of blue village to interest in entrepreneurship. Journal of Social Studies (JSS), 14(1), 80-89. https:// doi.org/10.21831/jss.v14i1.21655

Zomato Apps, 2018, versi 13.3.6 dari Play Store Android. 
Journal of Social Studies (JSS), Volume 16, Number 1, 2020: 19-34 